\title{
Self-Reliance and Social Networks: Explaining Refugees' Reluctance to Relocate from Kakuma to Kalobeyei
}

\author{
Alexander Betts (RSC, University of Oxford) \\ Naohiko Omata (RSC, University of Oxford) \\ Olivier Sterck (RSC, University of Oxford)
}

\begin{abstract}
In 2016, refugees in the Kakuma camps in Kenya were offered the opportunity to relocate to the new Kalobeyei settlement, which ostensibly offered a better set of opportunities. While it was portrayed by the international community as objectively better for refugees' autonomy and socio-economic prospects, most refugees in Kakuma viewed the opportunity differently. Less than $16 \%$ of refugees who heard about Kalobeyei were willing to be resettled there if land were provided. For refugees, the main justifications for the reluctance to move were linked to the likely disruption to existing social networks. This example of 'relocation for self-reliance' has wider implications for how we conceptualise self-reliance. Although UNHCR's definition of refugee self-reliance recognises that it applies to the community-level as well as the individual-level, self-reliance programmes that exclusively target individuals risk rejection by communities unless they also take into account the importance of social networks.
\end{abstract}




\section{Introduction}

Self-reliance has become an important goal of refugee policy-makers. It is defined by the United Nations refugee agency as 'the social and economic ability of an individual, a household or a community to meet essential needs in a sustainable manner' (UNHCR 2005). The definition therefore focuses not only on the individual but also recognises the role of communities. In theory, at least, the 'self' in self-reliance is a social self; not simply an autonomous individual but a person embedded in wider social relations. Furthermore, selfreliance entails autonomy and dignity in relation to the full range of societal domains necessary for human flourishing: economic, political, and cultural.

Nevertheless, although in theory UNHCR's understanding of 'self-reliance' recognises the role of communities, the practice mostly focuses on individuals. Most aid programmes relating to self-reliance, such as livelihoods programmes, vocational training, or cash transfers, for example, target individuals. Furthermore, the focus is predominantly economic, attempting to enhance market-based transactions or to promote income-generating activities (EastonCalabria 2015; Hovil 2007; Svedberg 2014).

The tension between individual and collective conceptions of self-reliance is especially evident in the case of relocation for self-reliance. The literature on development-induced displacement and resettlement (DIDR) recognises the tension between the individual and the collective in considering relocation that is justified by 'development' (Bennett and McDowell 2012; Cernea 1999, 2000; Mahapatra and Mahapatra 2000; Kibreab 2000). It recognises, for example, that even when people's functional needs, such as land, work, education, and food security are met through relocation, they may still be disadvantaged by the loss of social or cultural assets, for example. The issue of 'relocation for self-reliance' has not yet been explored in Refugee and Forced Migration Studies.

What if refugees, were hypothetically offered the opportunity to move geographically from a camp in which they face restrictions on their individual rights to an open settlement in which they enjoyed greater socio-economic entitlements and opportunities, would this be desirable? Almost certainly, this would be welcomed as welfare-enhancing from a purely individualistic view of self-reliance. But what if, in doing so, those refugees were forced to give up important social networks or sources of social capital that they regard as important?

In fact, this is precisely the scenario that has confronted refugees offered the opportunity to voluntarily relocate from the Kakuma refugee camps in North-East Kenya to a new settlement called Kalobeyei, which opened in 2016, just 3.5km away from Kakuma. The Kalobeyei Integrated Social and Economic Development Programme (KISEDP) is the first formal attempt to promote self-reliance in Kenya. The new 'hybrid settlement', which is purposed to accommodate both refugees and members of the host community, aims to "empower refugee and host communities and to achieve self-reliance through creating sustainable livelihood opportunities and providing access to mainstreamed services" (UNHCR 2017). The model 
represents a radical departure from Kenya's existing policy framework, based mainly on encampment (Milner 2009; Jansen 2018; Rawlence 2016) and illicit urban residence (Horst 2006; Lindley 2009; Carrier 2017; Campbell 2006).

Funded mainly by the European Union and now home to 38,000 refugees and around 2000 local Turkana, Kalobeyei offers a range of opportunities for market-based self-reliance that are unavailable in Kakuma. These include, cash-based assistance programme called 'Bamba Chakula', the world's first ever 'cash-for-shelter' programme in a refugee camp, an integrated design that enables refugees and host community members to live alongside one another and share markets, and the allocation of 'kitchen gardens' for subsistence agriculture. The approach is viewed as offering virtually unprecedented opportunities for market-based self-reliance. UNHCR's Head of Communications explained, “There is the old part of Kakuma. And then there is the new part, called Kalobeyei...It represents our new approach that is going global to refugee response...where we attract international development assistance as well as private investment" (UNHCR 2018).

Other research conducted by this article's authors suggests that, on its own terms, Kalobeyei's approach to economic self-reliance is working. It is leading to better food security outcomes, and greater perception of autonomy than for comparable populations in Kakuma. However, there is a paradox: when offered the opportunity to relocate from Kakuma to Kalobeyei most refugees do not want to move. This was the case at the start of the KISEDP and was still the case after its establishment. The questions is, why? If Kalobeyei seems to lead to better socioeconomic outcomes and offers greater socio-economic rights, why are most refugees more inclined to remain in Kakuma?

We explore that question using a mixed methods approach, based on a combination of survey methods, semi-structured interviews, and focus groups. Drawing upon survey evidence collected in Kakuma and Kalobeyei, we show that refugees have been consistently reluctant to move from Kakuma to Kalobeyei. We explain the reluctance to move by drawing upon both quantitative and qualitative data relating to the importance of social networks for refugees in Kakuma, as well as comparative analysis of the availability of such social networks in Kakuma and Kalobeyei. Overall, we argue that social networks and access to important forms of social capital explain the decision of many refugee in Kakuma to decline the opportunity to relocate to the Kalobeyei model, despite its ostensibly greater opportunities for self-reliance. The implication, we suggest, is that self-reliance must be conceived as going beyond a purely individualistic or economic perspective, to include an adequate recognition of the role of social networks and social capital within self-reliance.

\section{Context}

Kakuma sits in the remote and impoverished Turkana County in north-west Kenya. De facto Kenya's $7^{\text {th }}$ largest city, Kakuma is home to 180,000 refugees mainly from South Sudan and Somalia, and divides into four main camps (Focus Group). Opened in 1992, it has long been 
characterised by dependency and overshadowed by international focus on Kenya's large Dadaab camps on the other side of the country. Like all refugees in Kenya, the population has been subject to Kenya's strict policies limiting freedom of movement and the right to work.

Gradually, though, the local authorities in Turkana County recognised that the regional economy benefits enormously from the presence of refugees and international aid agencies. Reflecting this, in June 2015, the Government of Turkana County where Kakuma camp is located announced it would allocate some 1,500 hectares of land in Kalobeyei for a new settlement. This was meant to be a 'hybrid settlement' with the capacity to accommodate 60,000 refugees and 20,000 members of the local host community and to achieve selfreliance through creating sustainable livelihood opportunities and providing access to mainstreamed services". (UNHCR 2017)

In the initial planning, the Kalobeyei initiative had two primary purposes. First, it aimed to pilot a new approach towards the self-reliance of both refugees and host communities. The Government of Kenya, the Turkana County government and all key stakeholders have agreed to use this 'blank slate' land to develop a settlement that will promote the self-reliance of refugees and host communities by providing them with better livelihoods opportunities and integrated service delivery. This idea forms the basis of the Kalobeyei Integrated Social and Economic Development Programme (KISEDP), a multi-agency collaboration to develop the local economy and service delivery at Kalobeyei.

The KISEDP is a drastic shift from the Kenya's mainly camp-based refugee assistance programme. It is the first time that Kenya has ever promoted self-reliance for refugees and their integration in a host community. This pilot is a model in which hosts and refugees will share integrated services provided by aid agencies. In this pilot plan, both refugees and host communities will benefit from: 1) investments in basic infrastructure and access to social services; and 2) increased opportunities for supporting income generating activities. This integration approach is also aimed to nurture social cohesion between refugees and host communities.

Second, it aimed to decongest the current Kakuma camp. Initially set up for 100,000 people in 1991, Kakuma currently hosts some 165,000 refugees and asylum seekers, severely stretching its accommodation capacity. For recent years, Kakuma camp has been further over-capacitated due to the incessant influxes of refugees from South Sudan. Kalobeyei settlement is meant to alleviate this congestion by transferring a certain number of refugees from Kakuma to this new settlement.

The plans were warmly welcomed by the international community. On its website, UNHCR highlighted a launching of 'a ground-breaking programme that aims to improve the living conditions of refugees and host communities in Turkana County.' The Head of Development Cooperation of European Union - the major funder of the initiative - emphasised that the EU support focuses on interventions that promote self-reliance, through better livelihood opportunities and enhanced service delivery, building up resilience, and seeking longer-term solutions for refugees. 
We hope to enhance protection for refugees and host communities and catalyse development in Kalobeyei settlement so that it becomes a place in which refugees and the host communities live peacefully together, have access to social services and develop economic ties to build sustainable livelihoods (UNHCR 2017).

However, the positive phrases frequently used in KISEDEP, such as self-reliance, sustainable livelihoods, or longer-term solutions for refugees, have been often translated into or linked with programmatic priorities and resource allocation of international stakeholders. For instance, in UNHCR's presentation document on Kalobeyei initiative, the agency articulates that one of the overall objectives of KISEDEP is to: "re-orient the refugee assistance program to contribute to reduce over-dependence on humanitarian aid and prepare the refugees for sustainable solutions" (2016) while two other objectives are 1) improving the socio-economic conditions of the refugee and the host communities, and 2) preparing the host community to take advantage of emerging economic opportunities in upcoming extraction and potential irrigationfed agriculture. Meanwhile, the EU's 15 million Euro contribution, through its Trust Fund emphasized the link to managing irregular migration onto Europe.

The project was initially presented to refugees in Kakuma in 2016 as an opportunity for voluntary relocation to a new and pioneering model offering greater opportunities for selfreliance. They were shown plans that implied greater opportunities for self-reliance and integrated living alongside the local host community. It would be designed to encourage market-based exchange, and built on the principles of urban design. Ultimately, the trajectory of Kalobeyei changed because of the mass influx of refugees from South Sudan and Burundi, and very few refugees were relocated from Kakuma. Plans for relocation from Kakuma were put on hold.

\section{Methodology}

The data presented here is based on fieldwork between September and December 2016 in Kakuma refugee camp in Kenya. We employed both qualitative and quantitative methods. In order to develop our contextual understanding, we undertook a wide range of qualitative research techniques, including 30 unstructured and semi-structured interviews, 10 focus group discussions, and non-participant observation. We spoke to Congolese, Somali, South Sudanese, Rwandan and Ethiopian refugees as well as local Turkana people living nearby the Kakuma and Kalobeyei camps. Also, we interviewed a range of non-refugee stakeholders, including staff members of UNHCR, UNHCR implementing partners, WFP, FAO, and local government.

In November and December 2016, we collected survey data on 1,976 adults living in and around Kakuma camp. Our sample includes 461 refugees from South Sudan, 456 refugees from Somalia, 439 refugees from DRC, and 605 Turkanas from villages located around the camp. This research focuses on the sample of refugees. The sample was selected using stratified twostage cluster sampling design. We stratified the population of interest by country of origin, focusing on Somali, South-Sudanese, and Congolese. For each nationality, we then selected 20 
blocks in the camp, using sampling proportional to size. After mapping each selected block, we randomly selected eight households. We interviewed all adults living in household, up to a maximum of five. Sampling weights are taken into account in the analysis below, and standard errors are clustered at the block level.

The questionnaire included questions on demographics, economic activities, income, assets, networks, social protection, and health, as well a specific module on perceptions about the new Kalobeyei settlement. Questionnaires were translated in the languages of respondents.

This paper focuses on four questions. The first question is a yes/no question, which reads "Have you heard about the Kalobeyei refugee camp?" This question capture whether respondents have been informed about the new camp, either directly through UNHCR information campaign, or indirectly through their networks. The second and third questions are also yes/no questions, which read "Would you like to be resettled there?" and "Would you want to go there if provided with agricultural land?" These questions were only asked if respondents had responded "yes" to the first question, that is, if they had heard about the Kalobeyei refugee camp. The last question is a multiple-choice question asking "why" respondents would (not) like to be relocated in Kalobeyei refugee camp.

\section{Theory}

In recent years, discussions relating to refugees' economic 'self-reliance' have occupied a central seat in various policy arenas within the global refugee regime. In the new Global Compact on Refugees, the need to 'enhance refugee self-reliance' is stipulated as a key objective, alongside 'ease pressures on host countries'; 'expand access to third country solutions'; and 'support conditions in countries of origin for return in safety and dignity'. While the discourse of 'helping refugees help themselves' has become an increasingly visible part of UNHCR's approach and rhetoric towards refugee assistance and protection, relatively few studies delve further into the theoretical approaches to self-reliance as a concept (with exceptions including Meyer 2006, Kaiser 2008, Easton-Calabria and Omata 2018). This lacuna has led to a dearth of critical reflections of what self-reliance for refugees really means - both as it is conceptualised in discourse and as it is actualised in practice.

\section{Unpacking the 'self' in self-reliance}

The notion of self-reliance is inherently compound - involving the combination of two concepts: 'self' and 'reliance'. A common definition of 'reliance' refers to 'the state of depending on or trusting in something or someone' (Cambridge English Dictionary). As a concept, 'reliance' is arguably more straightforward when compared with the attempts of social scientists to define 'self'. As a core preoccupation of Western philosophy, the idea of self has been contentiously debated in the social sciences for centuries. In everyday parlance, it is customary for the idea of 'self' to be described as all the qualities, thoughts, preferences, motivations, and feelings that a person assumes to be his or her own (Charmaz 2007 in Tsekeris 2015). The theoretical underpinnings that assume the existence of an individual 'self' are core 
to modern liberal ideologies, in which an individual is conceived of as the "ultimate autonomous unit' (Bourdieu 2005).

While providing a full historical review of conceptual debates on notions of 'self' is beyond the scope of this paper, theorists in contemporary social sciences propose a wide array of frameworks for conceptualising the nature of self. Some consider the self to be a paradoxical amalgamation of independent and interdependent tendencies; this approach also recognises that any self is socially embedded and interactively created (Tsekeris 2015). Additionally, as described by Monceri, the concept of self intrinsically requires the existence of an 'other' in order to properly delineate a 'self"; she notes that "the development of the Self should be conceived as something that changes, that becomes, owing to its interaction with the given environment and with other Selves." (Monceri 2003). While the self has an element of individual autonomy, it is simultaneously intersubjective and socially situated rather than a reified, separate and lonely individual possession that can be defined in isolation (Spinelli 2001: 43 in Tsekeris 2015).

Through empirical observations, anthropologists have highlighted the fundamentally social and relational nature inhered in the construction of the self. According to Ferguson:

In the people-centric social systems of early colonial southern Africa (as anthropologists have long recognized), persons were understood not as monadic individuals, but as nodes in systems of relationships. While modern liberal common sense often universalizes an ideologically conceived liberal individual, and sees society as composed of transactions among such individuals, anthropologists of Africa have long insisted that relational persons do not precede relations of dependence; they are, instead, constituted by those relations (2012: 226).

However, as a compound concept, self-reliance is often conceptualised in everyday parlance as an individual's ability to think and act without the help of others. Put differently, a selfreliant person should be able to depend on himself or herself alone and to do things without assistance from others. In line with a liberal tradition of 'self-help', this thinking places emphasis on the idea of 'individual responsibility' and venerates 'the autonomous, independent, and self-sufficient individual as our ideal' (Fineman 2006: 135).

Yet, the construction of self as social and interactive process invites a question of self-reliance as individual responsibility. As Goodin (1985) stresses: "It is simply impossible for anyone ever to be completely self-reliant in that sense. Even the most extravagant champion of selfhelp, Samuel Smiles conceded that 'the help which we derive from others in the journey of life is of very great importance' (Smiles 1859, ch.1, in Goodin 1985: 31). In a ceaseless relational process of 'self-formation' (Ketokivi 2010), autonomy and dependence are indeed coupled. Crucially, a theoretical approach that takes the relational nature of selfhood into account also allows space for understanding the role of social relations and trust as people engage in socioeconomic lives and decision-making. 


\section{Self-reliance in aid programmes}

While UNHCR's definition of self-reliance (2005) includes the individual, household, and community levels, much of the practice of self-reliance focuses predominantly on the individual level. This is illustrated most clearly in the strategies adopted by aid agencies to promote self-reliance, in which vocational training, entrepreneurship, agriculture, cash transfers, and microfinance programmes are traditionally the bedrock (see Fiori et al 2016; De Vriese 2006; Crisp 2003). The technical approach to livelihoods aims to enable refugees to participate in labour markets with acquired skills or capital, suggesting that it is through the individual acquisition and development that widespread self-reliance will be achieved. Put differently, this approach focuses on increasing a refugee's human capital to rely on oneself in pursuit of his or her self-reliance (Fiori et al 2016).

Notably, the Global Compact on Refugees, which makes central the enhancement of refugee self-reliance, highlights this point:

Resources and expertise could be contributed to support: labour market analysis to identify gaps and opportunities for employment creation and income generation; mapping and recognition of skills and qualifications among refugees and host communities; and strengthening of these skills and qualifications through specific training programmes, including language and vocational training, linked to market opportunities, in particular for women, persons with disabilities, and youth (UNHCR 2018).

Emphasis on individual skill acquisition has coincided with broader neo-liberal values that valorise individuals' ability to navigate adversities alone. Critically, this, in turn, means that more collective and social aspects of self-reliance within and among refugee populations can be overlooked.

\section{The significance of social networks}

The current literature on refugees' economic lives points to the importance of social networks. Due to refugees' specific vulnerabilities as non-citizens in the host country, refugees are reliant on their personal and social ties, and constantly depend on these contacts in order to achieve socio-economic betterment in exile (see Palmgren 2014; Omata 2017; De Vriese 2006; Grabska 2005).

Research on refugees' mutual assistance offers some insight into the extent of collective agency and communal solidarity during exile. For example, amongst Somali refugees in Dadaab refugee camp in Kenya, the responsibility to assist those in need was deeply entrenched in camp life. According to Horst (2006b: 65), for resourceful refugees, there was a strong imperative to help destitute neighbours and to provide a certain percentage of their wealth to the needy. Similarly, among Sierra Leonean refugees in West Africa, inter-personal and household support networks were cemented through a stream of social obligations (Gale 2006: 
75). In South Africa, inter-household support within Congolese refugee communities serves as an informal safety-net to help refugees to survive through economic adversities (Amisi 2006).

These studies offer insight into the nature of a gradually constructed 'social world' (Marx 1990) that exist among refugees, hinting on some occasions at the development of communal solidarity beyond immediate kinship. These findings, in turn, offer different reflections with regard to predominant institutional approaches to refugee self-reliance, which has primarily focused on individualised support and human capital development.

Existing literature on Kakuma refugee camp highlights the crucial role of social relationships, often developed over protracted exile, in day-to-day survival of refugees. According to Gladdens (2013), informal social support from friends and neighbours constitutes a key coping strategy for many refugees living in the camp. Oka's studies $(2011 ; 2014)$ elucidate how refugees from different backgrounds interact with each other and build social relationships as a way to restore 'normality' in camp life, eventually leading to the construction of thriving camp economies despite a seemingly inhospitable environment. Ethiopian and Somali refugee businesspeople have built active commercial markets inside the camp through the development of trading networks in and outside the camp (De Montclos and Kagwanja 2000). Protracted displacement in Kakuma camp has resulted in an economic centre embedded in the local socioeconomic landscape, which has evolved over decades under humanitarian governance (Jansen 2016).

\section{Emplacement in protracted situations and meaning of relocation}

Crucially, social relations cannot be understood in insolation from the particular 'place' in which they are created and maintained over time. The linkage between social relations and places takes on particular significance in the context of protracted displacement.

Through building new social relationships, refugees not only establish strategies for subsistence but may also be able to gradually construct a meaningful place in exile (see Dudley 2011; Korac 2009). According to Turton (2004), the experience of forced displacement can encourage people to "struggle to make a place in the world, a place which makes action meaningful through shared understandings and a shared interpretation of action."

Additionally, Malkki (1995: 17) notes that processes of 'emplacement' are often the unrecognised flipside of displacement. During years or even decades of prolonged exile, intense and frequent interactions with other camp residents over years can often transform a mere location of camps into a 'relational home' (Taylor 2013; Ralph and Staeheli 2011). In turn, these socio-economic investments in exile may bind refugees to their current areas of settlement or lead to reluctance to leave a place of refuge (see Lubkemann 2008).

The linkage between social networks and place has profound implications for relocation and onward movement of refugee populations, as discussed later. In the field of economic sociology, Granovetter (1985) discusses the concept of 'embeddedness', which is the idea that 
economic relations between individuals are embedded within existing social relations. If the social and relational aspects involved in the formation of a 'self' are considered, what appears to be non-rational behaviour of 'atomized individuals' may be quite sensible or reasonable when situational constraints and social relations are considered (see Bourdieu 2005; Granovetter 1985).

We also know from the literature on relocation in Refugee Studies that while international actors have traditionally adopted a functionalist view of the reconstruction (or improvement) of conditions within a new settlement or repatriation context, displaced populations have been concerned about the disruption of existing social structures. For example, Michael Cernea (1997)'s 'Impoverishment Risks and Reconstruction Model', created for the World Bank, suggests that the key to successful relocation is simply to rebuild the major socio-economic dimensions needed for a high standard of living: landlessness, joblessness, homelessness, marginalisation, food insecurity, loss of access to common property, increased morbidity, and community disarticulation. Importantly, the model recognises the risk of 'community disarticulation'. However, critics argue social and cultural emplacement have been among the greatest challenges of relocation (Voutira and Harrell-Bond 1997; Nayak 1997; Kibreab 1997; Hirshon 1997; Mahapatra and Mahapatra 1997).

As explained above, the idea of KISEDEP based on self-reliance promotion was constructed largely by the international refugee regime without much involvement of refugees themselves. Drawing upon empirical evidence, we now turn to examine refugees' perceptions of proposed relocation to Kalobeyei and the role of social networks therein.

\section{Empirical findings}

Refugees' reactions to relocation to Kalobeyei

"We have heard about Kalobeyei...but we don't want to go there...."

Refugees and local hosts seem relatively well informed about the Kalobeyei initiative: 87.4 [79.2-92.7] percent of refugees and 71.1 [66.1-75.7] percent of Turkanas have heard about the initiative. As shown in Figure 1, information seems to have spread more widely among South Sudanese and Somali refugees compared to Congolese refugees. Different hypotheses could explain the slower diffusion of information among Congolese refugees compared to South Sudaneses and Somalis. At the time of the survey, South Sudanese new arrivals were being redirected to Kalobeyei camp, which explains why this community is very well informed about this initiative. In fact, some South Sudanese refugee households have been divided between Kakuma camp and Kalobeyei settlement due to different timing of arrival in Kenya.

On the other hand, a good proportion of Congolese refugees in Kakuma were less aware of Kalobeyei initiative or even did not know of its existence. The lower number and density of Congolese refugees in Kakuma could slow down the secondary transmission of information through networks. During the fieldwork in 2016, we were often bombarded by Congolese 
refugee interviewees with questions about the Kalobeyei settlement. During a focus group discussion, one Congolese refugee commented: "We only heard its name [Kalobeyei settlement] but we know nothing [about it]. If this is a good initiative for us, it will be interesting. Can you tell us what benefits we get there [Kalobeyei settlement]?"

Even among refugees who had heard about the Kalobeyei initiative, surprisingly, very few of them had ever seen or visited the settlement. In a focus group discussion with Somali refugees in Kakuma, one of the participants stated:

We have never seen it so we cannot say anything about Kalobeyei. I know UNHCR have organized some awareness raising activities but we have very little information about this place.

As the comment above illustrates, 'having heard of Kalobeyei' does not necessarily mean that refugees actually have adequate information about this new settlement. Participatory approaches and community engagement of refugees and host populations have been recognised as one of key guiding principles of KISEDEP to enhance community ownership (Terata et al 2017) however to what extent their participation was promoted and achieved remained questionable. As shown next, the absence of detailed information about Kalobeyei initiative has certainly affected refugees' willingness to move into Kalobeyei.

While most refugees have at least heard of Kalobeyei initiative, our results show that refugees are not interested to be relocated there, even if land is provided (Figure 2). Among those who heard about the Kalobeyei refugee camp, only 7.0 [4.0-12.0] percent of refugees seem interested in the initiative. This percentage rises to 15.7 [10.0-24.0] only if agricultural land is provided. Differences between refugees' nationalities are marginal, and not statistically significant.

In addition to the lack of detailed information about Kalobeyei, little trust in UNHCR seems to be driving the perception of uncertainty, thereby magnifying defiance against the project. As reported by a Congolese refugee during a focus group, "we heard the name of this settlement but have very little knowledge... We heard that we will be given a plot of land for farming but not sure whether this is really the case. We have very little trust and confidence. If we move to Kalobeyei, we may have to suffer more. It is too risky to go there. Also UNHCR is not very trusted. Previously they promised things but they often failed." 


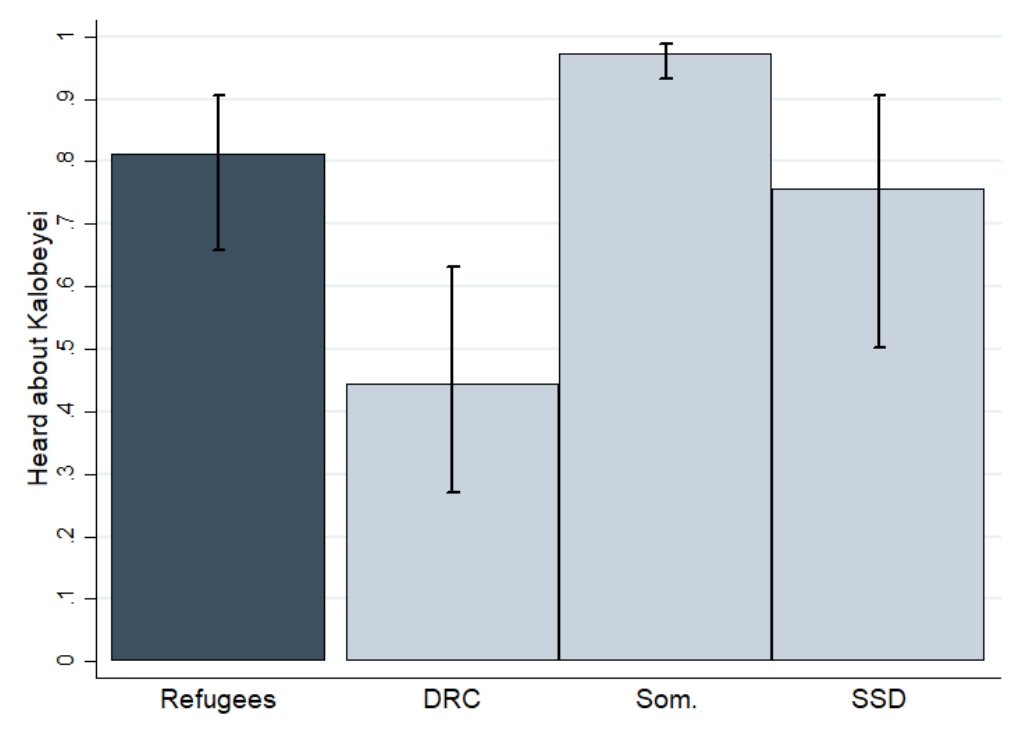

Figure 1: Information on Kalobeyei

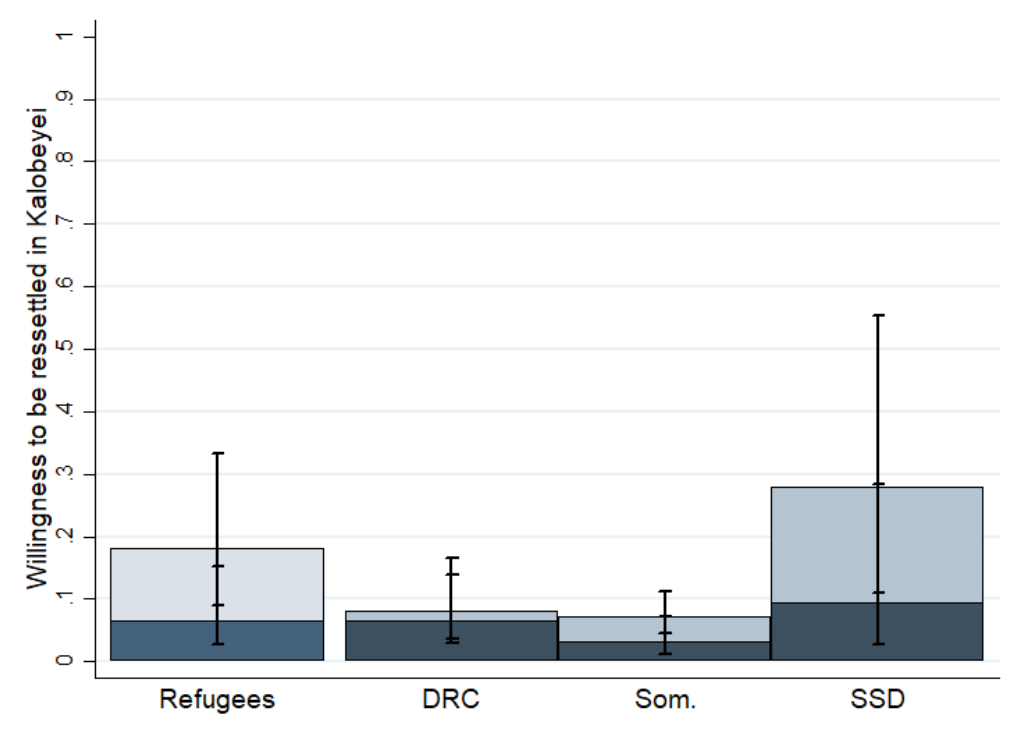

Figure 2: proportion of respondents willing to be resettled in Kalobeyei (subsample who heard about Kalobeyei). Note: for each bar, the lighter area at the top of the bar represents the proportion of respondents willing to move to Kalobeyei only if land is provided.

\section{Refugees' justifications}

While most refugees are unwilling to be resettled in the new Kalobeyei camp, justifications provided by refugees differ across different groups of refuges. While Figure 3 summarises refugees' reasons why they are not willing to relocate to Kalobeyei, the in-depth qualitative data sheds light on the importance of social relations and existing opportunity structures embedded in prolonged Kakuma camp. 
Given the limited access to detailed information about Kalobeyei settlement and the fact that most of settlement services in the settlement was under construction at the point of data collection, understandably, a considerable number of refugees prioritized maintaining access to existing opportunities and resources in Kakuma camp. For a significant proportion of South Sudanese new arrivals, relocation to Kalobeyei is not desirable because they fear losing access to social services (education, health facilities, energy, water) (46.3 [31.7 - 61.6] percent) as well as existing housing. The fear to lose existing opportunity applies to Congolese and Somali refugees' concerns for losing access to third-country resettlement if they move to the new Kalobeyei camp. As much as 42.6 [27.9-58.9] percent of Congolese refugees and 31.7 [24.6 39.8] percent of Somali refugees reported fearing access to third-country resettlement. Uncertainty was also emphasized during qualitative interviews: "If we move to Kalobeyei, what are our benefits? Do we lose access to resettlement?" (Congolese refugee). During our fieldwork in late 2016, the concern about loss of resettlement was especially magnified amongst refugees due to the US presidential election campaign. Given Trump's anti-migration policy, those who have been on resettlement procedure were very nervous and sensitive to anything that could jeopardize their resettlement possibility, and moving to Kalobeyei was viewed as one of such risks in the absence of detailed information about this new settlement.

The other major reason for reluctance for moving to Kalobeyei was the potential disruption of their communal support networks with other refugees in Kakuma camp. Refugees in Kakuma constantly rely on their fellow refugees when they face shortage of daily food and petty cash, who thereby offer important sources of social protection. For instance, many groups of refugees employ the practice of 'fictive households' - making an artificial household unit by bringing together members who are not related - as a survival strategy. This type of fictive household was especially popular amongst newly arrived South Sudanese youth since they often came alone to the camp as separated from other family members. For many of these refugees, moving to unfamiliar and unknown Kalobeyei meant the disruption of their existing communal protection system and was perceived as too risky a decision to make. Following is an excerpt of an interview with Dep, a 24-year old South Sudanese refugee in Kakuma, who is a member of one fictive household consisting of 12 unrelated individuals.

$M e$ : Why did you decide to live together?

Dep: At the reception centre, we realised our food ration is too small so we decided to cook together. We can help each other too.

$M e$ : How do you manage to survive in the camp?

Dep: We put all food ration and cook together. We also sometimes sell part of food ration for cash.

$M e$ : Have you heard of Kalobeyei?

Dep: Yes but I never saw it.

$M e$ : Are you interested in living there?

Dep: No, I am not. I don't want to be separated from others. 
The concern over losing communal ties is not limited within Kakuma camp. In Kakuma town, there is a noticeable presence of Somali-Kenyan business people, and some Somali refugees have been employed by them as shopkeepers or manual labour outside the camp. In addition, there have been religious and clan-based interactions between refugees and Somali-Kenyans. The relocation to Kalobeyei can distance their existing relationship that can provide the refugees an avenue to socio-economic opportunities.

Some refugees expressed the fear of losing their existing income-generating means by moving to Kalobeyei. A good number of refugee business owners in Kakuma remained cautious about moving to Kalobeyei in that they did not see this new settlement as an 'attractive market' as the UN stakeholders aimed to project. When we asked Daniel, an Ethiopian refugee who runs a medium-sized grocery shop in Kakuma camp for several years, about his interest in moving to Kalobeyei, he responded:

It will be very hard to survive there [Kalobeyei]. I have seen there a few times but markets are underdeveloped and there were not many economic activities there...I am not interested in transferring my business there. Also, it will be very costly to rebuild my shop.

Daniel's concern was echoed by other refugee entrepreneurs in Kakuma camp. In particular, those who have had established business in Kakuma camp were averse to moving to Kalobeyei where they might end up losing their access to markets and customers. As these examples from different refugees' nationalities indicate, a large number of refugees in Kakuma camp have constructed their economic strategies based on personal relations embedded in the camp environment. These livelihood assets are so-called 'location-specific assets' (Faist 2000: 299), which are not easily transported to other sites.

A large proportion of both Somali and Congolese refugees responded to Kalobeyei relocation that they 'are used to live in Kakuma' or 'do not want to start a new life again' given the absence of clear benefits in doing so. During a focus group discussion, a Congolese salon worker emphasized uncertainty and lack of clear benefits: "We feel like there will be more challenges in Kalobeyei than Kakuma. It is too unpredictable and too risky. Also in Kakuma we have much better networks. If we move, we will also lose some customers." The unwillingness to be relocated particularly salient in the voices of Somali refugees who had already been relocated from Dadaab camp to Kakuma camp. A Somali refugee noted during a focus group discussion: "Many of us were forced to move from Dadaab to Kakuma before. Initially life in Kakuma was not easy. Why do we have to suffer again to rebuild our life?"(Somali refugee)

Provision of a plot of land for farming, a central pillar of self-reliance promotion in Kalobeyei, did not appear to be an attractive incentive for many refugees in Kakuma. Refugees, especially those who have been in Kakuma for years, think that commercial farming is not a viable option due to the arid climate and poor soil quality. Furthermore, they have experienced the limited access to water in Turkana area, which is an indispensable resource for agriculture. A 
Congolese refugee in Kakuma camp with farming background summarised these fundamental issues as follows: "There is very little water access in this area. The soil is not fertile. We know it is not easy to do farming [even if we are given land in Kalobeyei]'. In sum, refugees do not seem particularly interested by the new scheme of Kalobeyei's self-reliance model offered by UNHCR and international community. Instead, the empirical data presented above underline the importance of their social relations embedded in Kakuma camp during exile. In the following section, the data on refugees' social protection provides further evidence to this finding.

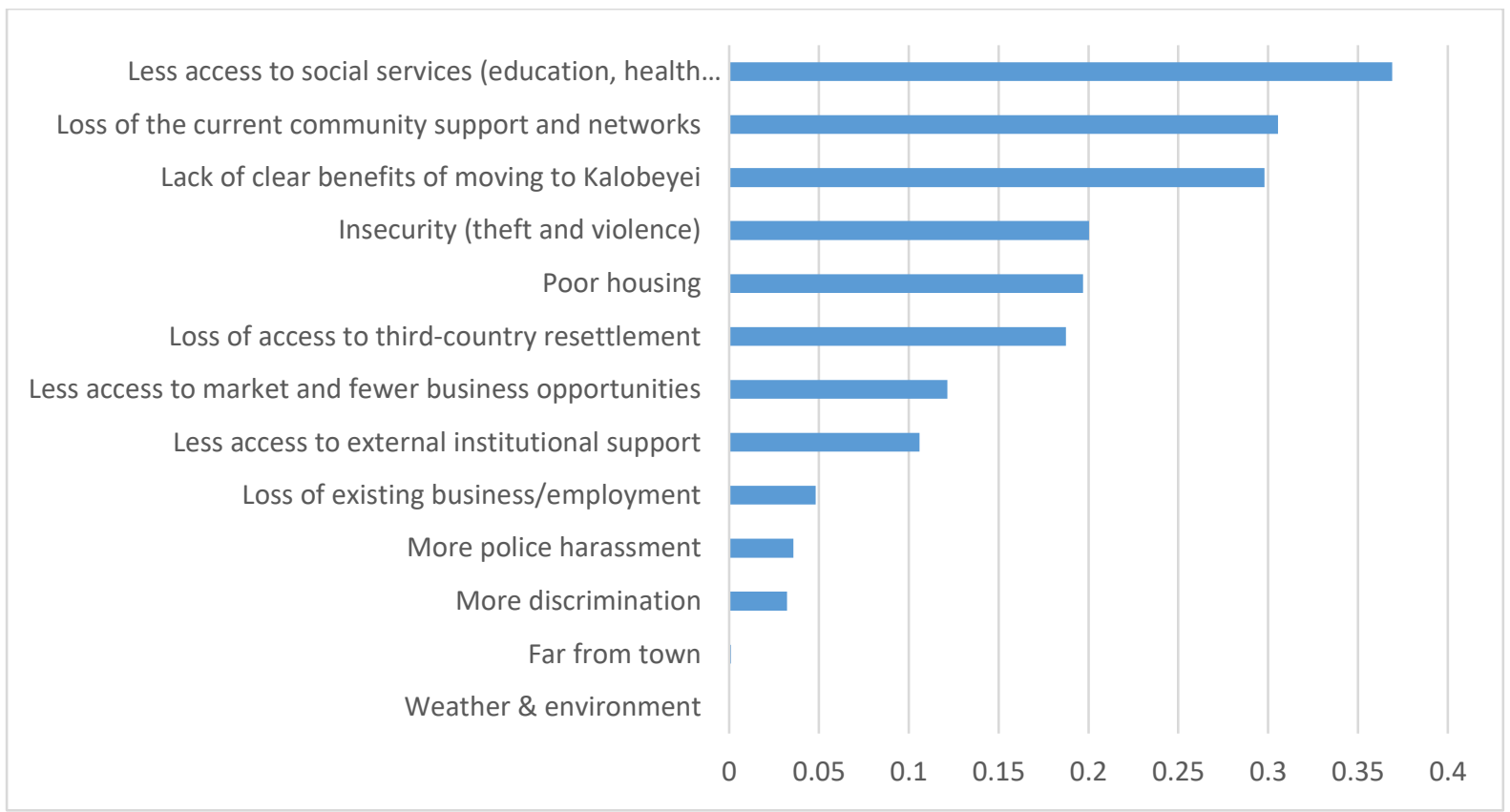

Figure 3: Justification provided by refugees

\section{Social Networks and Social Protection in Kakuma}

To understand the high level of unwillingness of refugees to relocation to Kalobeyei, it is essential to look into how different groups of refugees in Kakuma have been surviving there by relying on other fellow refugees. As explained above, our survey questionnaire included a series of questions about to whom they would most likely turn to if faced with different kinds of need.

It is often assumed that refugees' main sources of social protection come from international organisations or NGOs. In practice, though, refugees themselves are an important source of social protection for other refugees. Indeed, our data from Kakuma illustrates how significant this is, with friends, family, and community being widely cited as far more important sources of social protection than international organisations as illustrated in following figures. 
This was especially so when refugees need to search for petty cash for emergency or daily food. Elembe, one of Congolese community leaders in Kakuma, who has been living in the camp since 2010, explained the practice of reciprocal support amongst Congolese refugees

In case of family death and severe illness [of other Congolese refugees], we assist each other by collecting donation... [In case of daily food] we go to our friends or neighbours in the camp. If it is petty cash, we still ask our friends or neighbours but it is not easy to get it. You have to have a very strong relationship [with that person who can lend cash].

We also asked refugees where they would go if they wanted to obtain a loan of 10,000 KES to launch a business. As the Figure below highlights, a proportion of refugees who would refer to UNHCR or to an NGO increases, especially with South-Sudanese refugees, yet still for Congolese and Somali refugees, their relatives or community remain main reference points. In particular, Somali refugees resort to informal lending from within their own community. In Kakuma camp, Somali refugees obtained loans from members of the same clanship or Somali Kenyan business owners in Kakuma town. Another means to obtain financial capital for refugees is to create a rotating savings and credit association. For instance, within the Somali community, there are numerous 'ayutos', a type of rotating community finance mechanism.

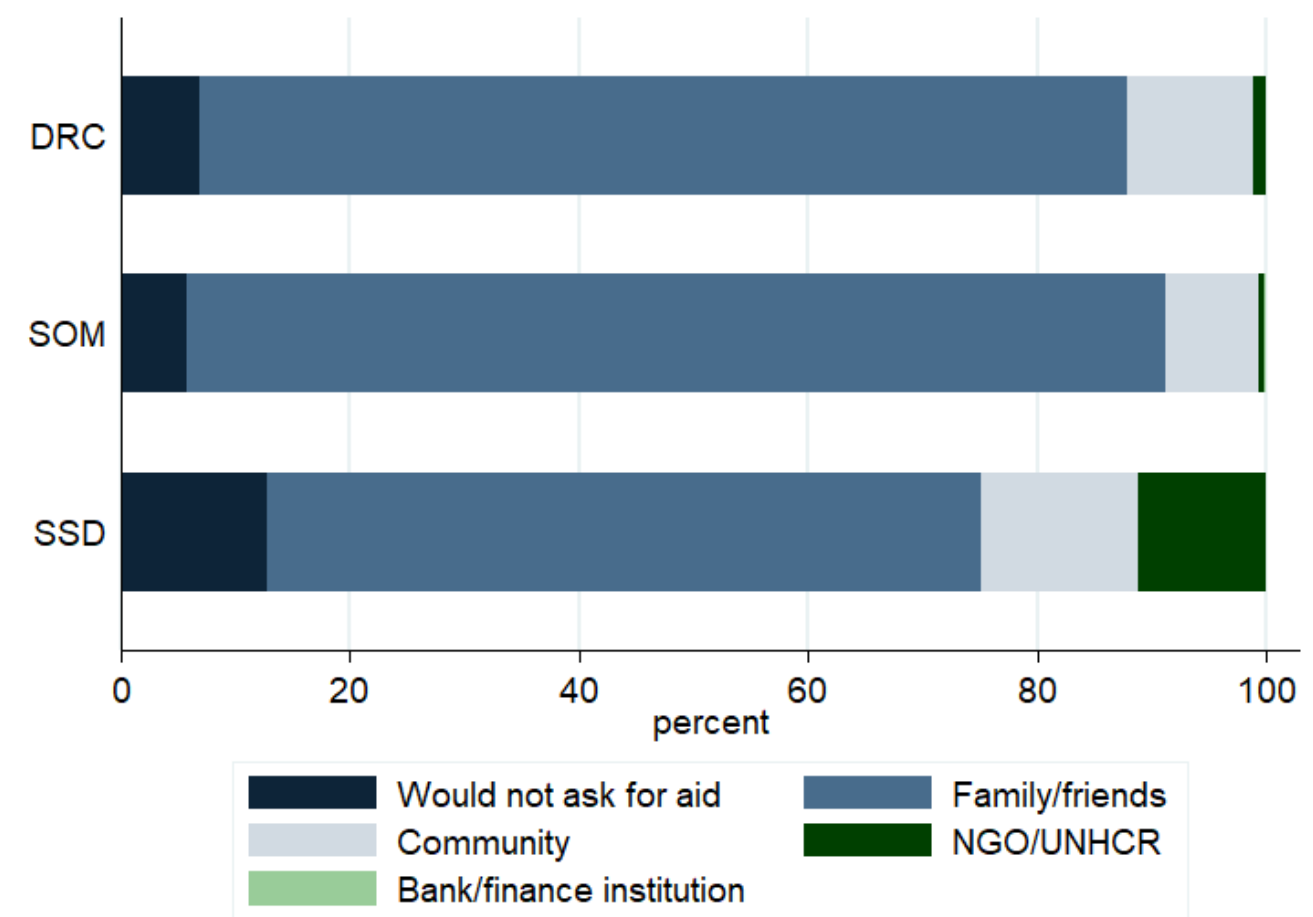

Figure 4: Who would you ask if you are looking for 500 KES for an emergency, for example to purchase medicine? 


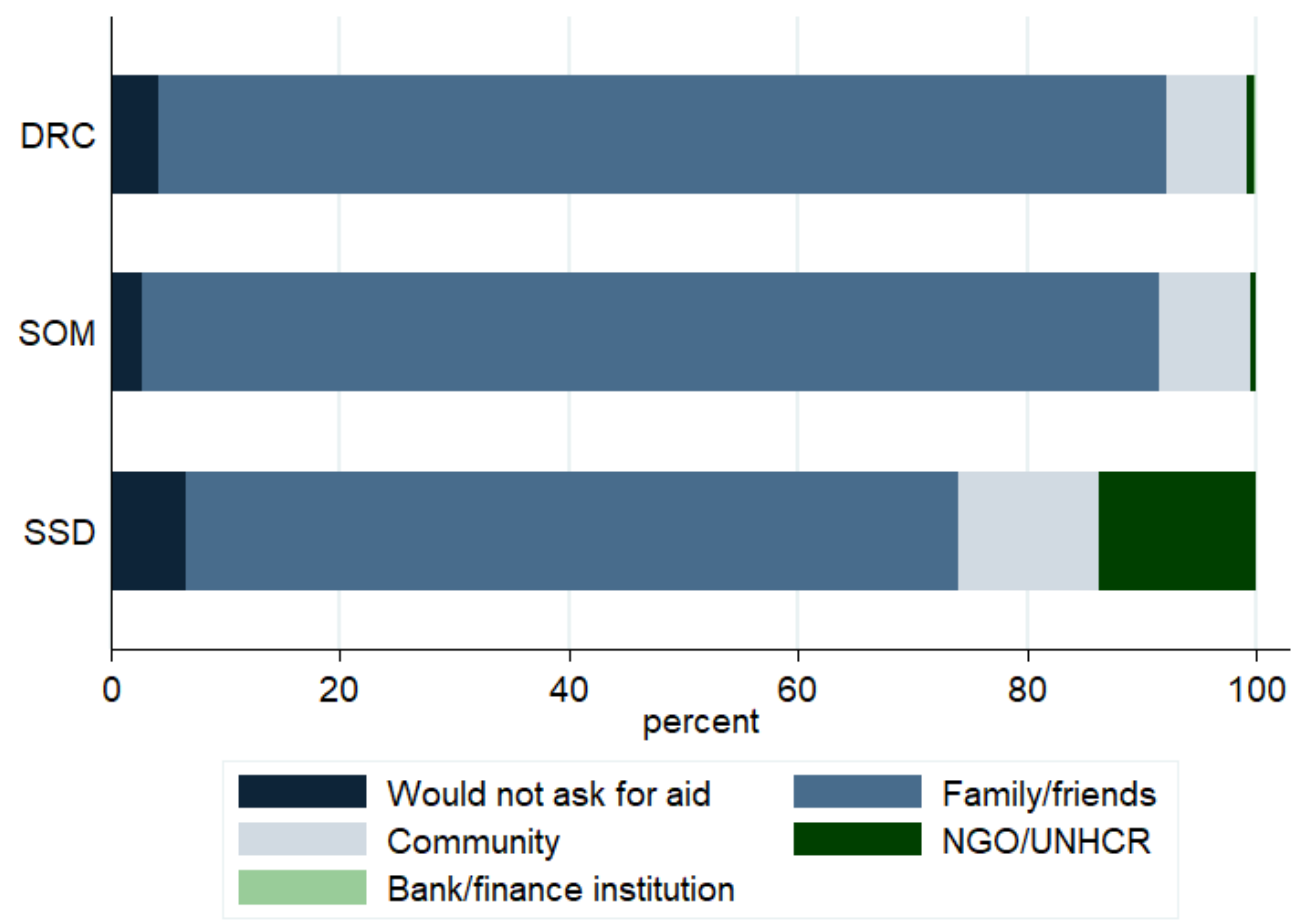

Figure 5: Who would you ask if you do not have food to eat?

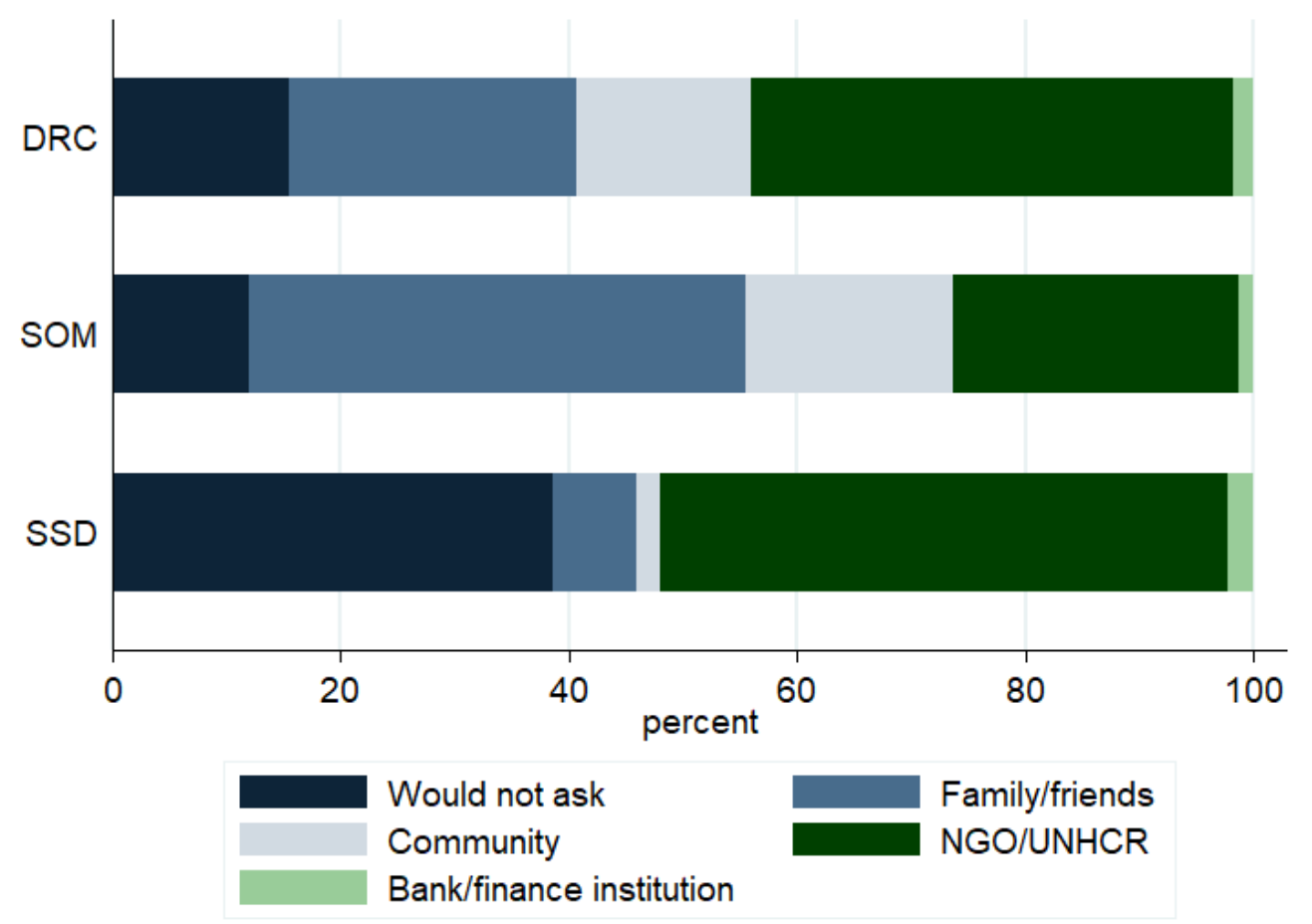

Figure 6: Who would you ask if you are looking for large amount of money to start or expand a business? 


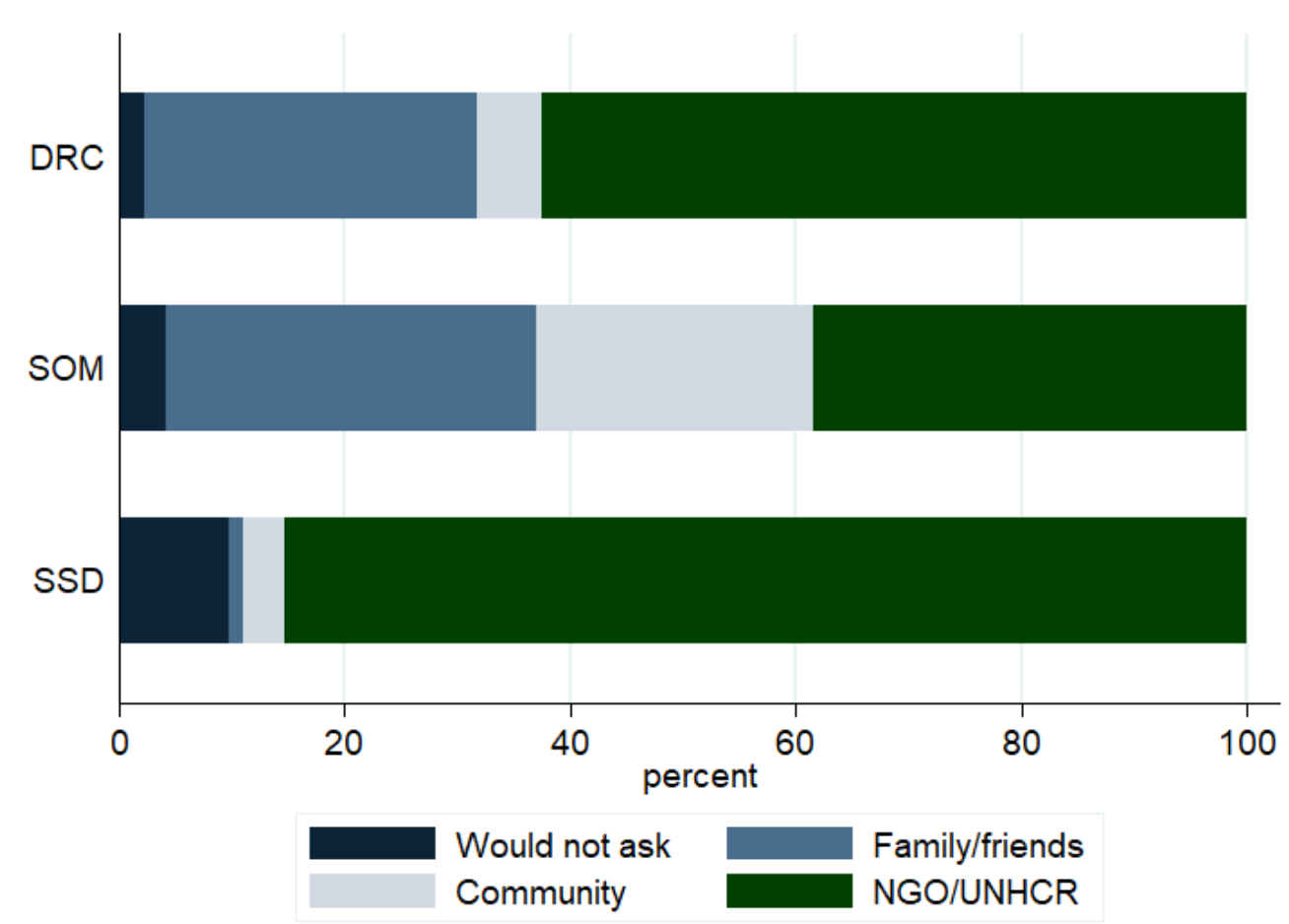

Figure 7: Who would you ask if you are looking for a job?

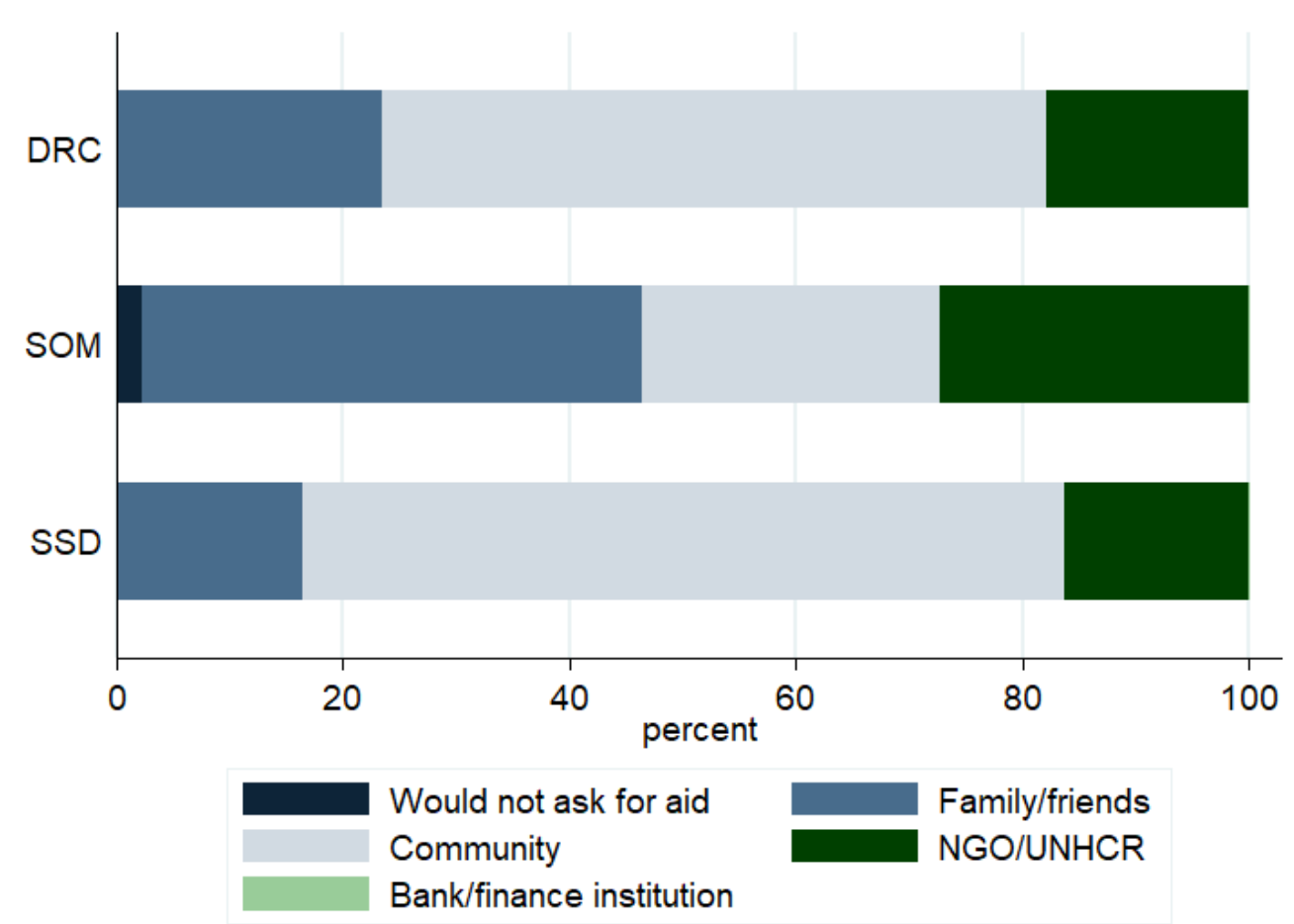

Figure 8: Who would you ask if you have problems with the police? 
The significance of communal networks was echoed by refugees in their job-searching. For example, we came across a number of Congolese refugees who work as boda drivers in the camp. The vast majority of them are employed by wealthier Congolese refugees who were able to afford these motorbikes and they are sharing profits. For these employed drivers, relocation to Kalobeyei means separation from their communal bonds that can provide livelihood sources.

Another important function of community is provision of physical protection from Kenyan authorities. In Kakuma camp, refugees are frequently and systematically subject to widespread police harassment and are forced to pay bribes, otherwise arrested and detained for no legitimate reasons (see Betts et al 2018). The refugees in Kakuma have been dealing with police harassment and payment of bribe through communal support. All refugee groups in Kakuma have organized their own leadership structure, which usually deals with these issues with the Kenyan police. In a focus group discussion, one Congolese refugee elder, a former member of Congolese representation, explained how Congolese community responds to this issue:

If arrested by the police, we first call our relatives and friends to bring money to the police [as bribe to be released]. But if they don't have enough money, we call Congolese refugee leaders. They will mobilise the Congolese community and collect money to release their fellow.

As illustrated with these empirical examples, various types of mutual assistance are well structured in Kakuma camp and are recognised as a main source of protection for camp residents. Importantly, these support mechanisms have been nurtured over years of reciprocal relationship inside the camp community and 'emplaced' in the camp. Relocation to Kalobeyei means dissection from this communal defence mechanism.

\section{Conclusion}

When thinking about relocation for self-reliance, we need to take seriously the centrality of social network as a basis for self-reliance. Although UNHCR's definition of self-reliance includes the individual, household, and community level, there remains a tendency to emphasis the individual dimensions of self-reliance, and underplay the social embedded nature of self-reliance. What appear to be individual livelihood strategies or sources of social protection are invariable embedded within a wider socio-cultural context, and connected to established social networks. To recognise this relies upon adopting a more collective understanding of self-reliance in refugee contexts.

The context of proposed refugee relocation from Kakuma to Kalobeyei offered a methodologically fascinating opportunity to explore these themes. This is because it proposed to refugees the possibility to move from an 'old camp' to a 'new settlement' with an ostensibly better set of opportunities. While it was portrayed by the international community as objectively better for refugees' autonomy and socio-economic prospects, most refugees in Kakuma viewed the opportunity differently. Only 15.7 percent of refugees who heard about 
Kalobeyei were willing to be resettled there if land were provided. They viewed relocation as a source of disruption that risked displacing them from their existing social networks, which to many refugees were an important source of socio-economic opportunity.

Social and communal understandings of self-reliance appear to explain refugees' reluctance, which can be interpreted as 'reasonable' even though they may not appear as 'rational' to the international community. This distinction emerges from Pierre Bourdieu (2005: 9), who suggests that 'The dispositions acquired through learning processes associated with protracted dealings with the regularities of the field, these dispositions are capable of generating behaviours and even anticipations which would be better termed as 'reasonable' than 'rational'. Indeed, for refugees, this reasonableness receives some affirmation through the consistency of perspectives across the Kakuma community during our qualitative survey.

The gap between international community expectations and refugee perceptions highlights the need for far greater consultation with refugees in the design and conception of new 'designed' models. Indeed, the initial phase of Kalobeyei planning was predominantly donordriven and took place without significant local consultation with refugees, despite the emphasis within the KISDEP plans on including a gradually increasing role for refugee and host community involvement in programme co-design. Indeed, hindsight suggests that refugees' perspectives would have been useful both to build greater trust and confidence in the initial Kalobeyei plans and in order to flag the structural barriers to relocation. Following James Ferguson (1990)'s work, the Kalobeyei model highlights the perils of top-down planning that misinterprets the socio-culturally informed perceptions of the target community.

The data presented in this paper is based on the earliest phase of Kalobeyei's roll out in 2016, and does not speak to the long-term 'success' of economic outcomes. But it does point to elements of potential mismatch between the international community's understanding of selfreliance and the community's own understanding. If self-reliance is about the ability of a community to meet essential needs, then, on a global scale, collaborative approaches are needed to understand communities' own interpretations of their needs, and the importance of social networks for the attainment of self-reliance. While the centrality of social network for refugees' strategies are widely recognised within the Refugee Studies literature (Palmgren 2014; Omata 2017; De Vriese 2006; Grabska 2005; Horst 2006; Jansen 2016), our original contribution is to explore what these means in the context of relocation for self-reliance, demonstrating that a seemingly 'rational' relocation is likely to be resisted if it fails to take into account the socially embedded and geographically emplaced character of refugees' social and economic strategies. 


\section{References}

Amisi, B. (2006) "An Exploration of the Livelihood Strategies of Durban Congolese Refugees," UNHCR Working Paper No.123, New Issues in Refugee Research, UNHCR, Geneva.

Betts, A., Omata, N. \& Sterck, O. (2018) Refugee Economies in Kenya, Oxford: Refugee Studies Centre.

Bourdieu, P. (2005) The Social Structures of the Economy, Cambridge: Polity Press.

Cernea, M. and McDowell, C (2000) Risk and Reconstruction: Experiences of Resettlers and Refugees, Washington D.C.: The World Bank.

Crisp, J. (2003) "UNHCR, refugee livelihoods and self-reliance: a brief history" http://www.unhcr.org/research/RESEARCH/3f978a894.html

De Vriese, M. (2006) "Refugee livelihoods: a review of the evidence", Evaluation and Policy Analysis Unit, UNHCR, Geneva.

De Montclos, M.A.P. and Kagwanja, P.M. (2000) "Refugee Camps or Cities? The Socioeconomic Dynamics of the Dadaab and Kakuma Camps in Northern Kenya" Journal of Refugee Studies 13 (2): 205-222.

Dudley, S. (2011) Feeling at home: producing and consuming things in Karenni refugee camps on the Thai-Burma border, Population, Space and Place, 17: 742-755.

Easton-Calabria, E. and Omata, N. (2018) "Panacea for the refugee crisis? Rethinking the promotion of 'self-reliance' for refugees", Third World Quarterly, DOI:10.1080/01436597.2018.1458301

European Union (2016), 'Regional Development and Protection Programme in Kenya: Support to the Kalobeyei Development Programme', July 2016-June 2019, Available at https://ec.europa.eu/trustfundforafrica/region/horn-africa/kenya/regional-development-andprotection-programme-kenya-sup-port-kalobeyei_en

Ferguson, J. (1990). The Anti-Politics Machine; Development, Depoliticization, and Bureaucratic Power in Lesotho. Princeton: Princeton University Press.

Ferguson, J. (2012) "Declarations of Dependence: Labour, Personhood, and Welfare in Southern Africa." Journal of the Royal Anthropological Institute 19 (2): 223-42. 
Fineman, M. A. (2006) "Dependency and Social Debt." In Poverty and Inequality, edited by David B. Grusky and Ravi Kanbur, 133-52. Studies in Social Inequality. Palo Alto: Stanford University Press.

Fiori, J., Rigon, A., Carpi, E., Dicker, S., Field, J., Mookherjee, Y., Tiwari, A. D., Espada, F., Boano, C., and Johnson, C. (2017), Overview: Refugee self-reliance in urban markets Halba, Delhi, and Thessaloniki, in Making Lives: Refugee Self-Reliance and Humanitarian Action in Cities, (eds) Fiori, J and Rigon, A., London: The Humanitarian Affairs Team, Save the Children, 105-115

Carrier, N. (2017), Little Mogadishu: Eastleigh, Nairobi's Somali Global Hub. London: Hurst.

Gale, L.A. (2006) "Sustaining relationships across borders: Gendered livelihoods and mobility among Sierra Leonean refugees”, Refugee Survey Quarterly, 25 (2): 69-80.

Gladden, J. (2013) "Coping strategies of Sudanese refugee women in Kakuma refugee camp, Kenya”, Refugee Survey Quarterly, 32 (4): 66-89.

Goodin, R. E. (1985) "Self-Reliance Versus the Welfare State." Journal of Social Policy 14 (1): $25-47$.

Grabska, K. (2005) "Living on the margins: The analysis of the livelihood strategies of Sudanese refugees with closed files in Egypt", Forced Migration and Refugee Studies, Working Paper No. 6, American University in Cairo.

Granovetter, M. (1985) "Economic Action and Social Structure: The Problem of Embeddedness", The American Journal of Sociology, 91 (3): 481-510.

Hirschon, R. (2000) The creation of community: well-being without wealth in an urban Greek refugee locality, in Risk and Reconstruction: Experiences of Resettlers and Refugees, (eds) Cernea, M. and McDowell, C., N.W. Washington DC: The World Bank, 393-411.

Horst, C. (2006) Transnational Nomads. How Somalis cope with refugee life in the Dadaab camps of Kenya, Oxford: Berghahn Books.

Jansen, B. (2016) "'Digging Aid': the camp as an option in East and the Horn of Africa", Journal of Refugee Studies, 29 (2): 149-165.

Jansen, B (2018), Kakuma Refugee Camp: Humanitarian Urbanism in Kenya's Accidental City. Aldershot: Zed Books.

Hovil. L. (2007), 'Self-settled Refugees in Uganda: An Alternative Approach to Displacement?', Journal of Refugee Studies, 20(4): 599-620. 
Kaiser, T (2008). "Sudanese Refugees in Uganda and Kenya." In Protracted Refugee Situations: Political, Human Rights and Security Implications, edited by Gil Loescher, James Milner, Edward Newman, and Gary Troeller. Tokyo; New York: UNU Press.

Ketokivi, K. (2010) "The relational self, the social bond and the dynamics of personal relationships: A sociological analysis", Sociology Research Reports No. 263, Helsinki: University of Helsinki.

Kibreab, G. (2000) Common property resources and resettlement, in Risk and Reconstruction: Experiences of Resettlers and Refugees, (eds) Cernea, M. and McDowell, C., N.W. Washington DC: The World Bank, 293-331.

Korac, M. (2009) Remaking Home. Oxford: Berghahn.

Lindley, A. (2009), The Early Morning Phone Call. Oxford: Berghahn.

Lubkemann, S.C. (2008). Culture in Chaos, Chicago: The University of Chicago Press, Inc.

Mahapatra, L.K. and Mahapatra, S. (2000) Social re-articulation and community regeneration among resettled displaces, in Risk and Reconstruction: Experiences of Resettlers and Refugees, (eds) Cernea, M. and McDowell, C., N.W. Washington DC: The World Bank, 431-444.

Malkki, L. (1995) Purity and exile, Chicago: The University of Chicago Press, Inc.

Marx, E. (1990) “The Social World of Refugees: A Conceptual Framework", Journal of Refugee Studies, 3 (3): 189-203.

Meyer, S. (2006) 'The 'Refugee Aid and Development' Approach in Uganda: Empowerment and Self-Reliance of Refugees in Practice'." New Issues in Refugee Research, UNHCR Working Paper No 131, UNHCR, Geneva.

Milner, J. (2009), The Politics of Asylum in Africa. London: Palgrave MacMillan.

Monceri, F. (2003) The transculturing self: a philosophical approach, Language and Intercultural Communication, 3 (2): 108-114.

Nayak, R. (2000) Risks associated with landlessness: an exploration toward socially friendly displacement and resettlement, in Risk and Reconstruction: Experiences of Resettlers and Refugees, (eds) Cernea, M. and McDowell, C., N.W. Washington DC: The World Bank, 79123 
Oka, R. (2011) "Unlikely cities in the desert: The informal economy as casual agent for permanent 'urban' sustainability in Kakuma refugee camp, Kenya”, Urban Anthropology, 40 (3-4), 223-262.

Oka, R. (2014) "Coping with the refugee wait: the role of consumption, normalcy, and dignity in refugee lives at Kakuma Refugee Camp, Kenya", American Anthropologist, 116 (1): 23-37.

Omata, N. (2017) The Myth of Self-Reliance: Economic lives inside a Liberian refugee camp, Oxford: Berghan Books.

Palmgren, P. (2014) "Irregular Networks: Bangkok Refugees in the City and Region1." Journal of Refugee Studies 27(1): 21-41.

Ralph, D. and Staeheli, L. (2011) Home and migration: mobilities, belongings and identities, Geography Compass, 5/7: 517-530.

Rawlence, B. (2016), City of Thorns. New York: Picador.

Svedberg, E. (2014), Refugee Self-Reliance in Nakivale Refugee Settlement, SIT Study 1778. https://digitalcollections.sit.edu/isp_collection/1778

Taylor, H. (2013) Refugees, the state and the concept of home, Refugee Survey Quarterly, 32 (2): 130-152.

Terada, Y., Evans, D. and Mwaniki, D. (2017) Planning for the integration of refugees and host communities in Turkana County, Kenya, Forced Migration Review, 55: 52-54.

Tsekeris, C. (2015) Contextualising the self in contemporary social science, Contemporary Social Science, 10 (1): 1-14.

Turton, D. (2004). Conceptualising Forced Migration. Oxford: University of Oxford, Refugee Studies Centre Working Paper No. 12.

UNHCR (2005) Handbook for Self-Reliance, Geneva: UNHCR.

UNHCR (2016) The Kalobeyei Integrated Social and Economic Development Program (KISEDP), Kakuma, Kenya: UNHCR.

UNHCR (2017) Unique EU Programme to Benefit Refugees and Host Communities in Kalobeyei, Available at http://www.unhcr.org/ke/2078-unique-eu-programme-to-benefitrefugees-and-host-communities-in-kalobeyei.html (accessed 25 May 2018).

UNHCR (2018a) Interview with Head of Communications, Al-Jazeera, 5 June, https://m.youtube.com/watch?v=S3nj38zTQKs 
UNHCR (2018b), From commitment to action: Highlights of progress towards Comprehensive Refugee Responses since the adoption of the New York Declaration, Geneva: UNHCR.

Voutira, E. and Harrell-Bond, B. (2000) "Successful" refugee settlement: are past experiences relevant?, in Risk and Reconstruction: Experiences of Resettlers and Refugees, (eds) Cernea, M. and McDowell, C., N.W. Washington DC: The World Bank, 56-78 